\section{Original Article}

J Immunol Clin Microbiol 2016; 1(3):

DOI: $10.5455 / 10.5455 /$ jicm.18.20161028102134

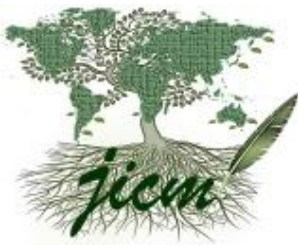

J Immunol Clin Microbiol

\title{
Characterization of lymphocyte infiltration in molar pregnancies
}

\author{
Haider Fasial $^{1}$, Jabbar Salman Hassan ${ }^{1 *}$, Manar Mustafa ${ }^{2}$, Haleema Salman ${ }^{1}$ \\ ${ }^{1}$ Department of Microbiology, College of Medicine, Al-Nahrain University, Baghdad, Iraq. \\ ${ }^{2}$ Department of Histology, College of Medicine, Middle Technical University, Baghdad, Iraq.
}

\begin{abstract}
Background: In normal pregnancy around 30\% of stromal cells in decidualised endometrium are leucocytes, lymphocyte subtypes may play a role in the pathogenesis of molar pregnancies. The aim of the study is to investigate the pattern of infiltrating lymphocytes in paraffin embedded tissue sections obtained from molar pregnancies.

Material and Methods: This study included thirty-five archived paraffin-embedded samples of molar pregnancies; divided into 16 incomplete and 19 complete hydatid mole. Then dual immunofluorescence staining was used for phenotyping of lymphocytic infiltrate (CD3- CD19) and (CD4-CD8). Independent sample t-test was used to compare the mean cell counts between different study groups.

Results: There is higher T cells (CD3) infiltrate in complete hydatid mole than normal placental tissue ( $\mathrm{p}=0.003)$ and not significant with incomplete hydatid mole ( $\mathrm{p}=0.089$ ). Plasma cells (CD19) were higher in both complete hydatid mole CHM ( $\mathrm{p}=0.012)$ and incomplete hydatid mole iCHM ( $\mathrm{p}=0.013)$. Cytotoxic cells (CD8) were none significant in all groups while Helper cells (CD4) were significantly higher in CHM ( $p=0.017)$ and iCHM $(p=0.025)$.

Conclusion: The higher tissue infiltration with plasma cells and helper cells in both CHM and iCHM highlight the importance of these cells in molar pregnancy pathogenesis.
\end{abstract}

Key words: Hydatid mole, lymphocytes infiltration, Complete hydatid mole, incomplete hydatid mole.

\section{Introduction}

Leukocytes comprise the majority of the developing placenta includes maternal blood and decidual cells (1). These cells giving different biological molecules, especially cytokines and growth factors, which play an important role to enhance the placental development and function. Study role of these cells during pregnancy critical to our comprehension of the achievement or disappointment of a pregnancy (2).

*Corresponding Author: Jabbar Salman Hassan. Department of Microbiology, College of Medicine, Al-Nahrain University, Baghdad, Iraq. E-mail: jabbarsalman30@yahoo.com Received: Aug 23, 2016. Accepted: Oct 28, 2016 Published Online: Jan 27, 2017.
In an ordinary early pregnancy, the proportion of CD8+ and CD4+ T cells is around, 2.5-3:1 (3). The quantities of $\mathrm{T}$ cells diminish in the early decidua contrasted with a non-pregnant endometrium (4).

It has been found that decidual CD8+T cells have cytolytic activity, don't bring out a prevalent local intrauterine, Th2 sort cytokine environment, and control trophoblast intrusion into the decidua. A bigger rate of decidual CD3+T cells expresses CD38, HLA-DR and VLA-1, than of peripheral blood CD3+T cells (5).

This is an Open Access article distributed under the terms of the Creative Commons Attribution Non-Commercial License (http://creativecommons.org/licenses/bync/4.0/) which permits unrestricted non-commercial use, distribution, and reproduction in any medium, provided the original work is properly cited. 
Hydatidiform mole is a gestational trophoblastic disease characterized by abnormal proliferation of trophoblast cells (6) with no fetus (7). In contrast, partial hydatidiform moles usually result from the fertilization of a normal ovum by two spermatozoa, (8) and affect only part of the placenta. Similar to a typical early pregnancy, obtrusive additional villous trophoblast cells of complete and partial hydatidiform moles are reactive to the monomorphic determinant however not to polymorphic epitope of class I HLA antigens (9).

In hydatid form moles, positive CD3, CD8 lymphocytes and mast cell tryptase are expanded, macrophages are unchanged while NK cells are diminished (10). This proposes a dysfunction in the control of the trophoblast attack by decidual leukocytes, maybe through their creation of growth factors and cytokines in gestational trophoblastic diseases.

This study aimed to investigate the pattern of infiltrating lymphocytes in paraffin embedded tissue sections obtained from molar pregnancies.

\section{Material and methods}

\section{Tissues}

Formalin-fixed, paraffin-embedded archival decidual tissues from sixteen partial and nineteen complete hydatidiform moles evacuated during the first trimester were retrieved from the archive files of the Histopathology department, AL-Emamain Medical City, Baghdad.

Fifteen normal (first trimester) tissue interface were obtained with elective termination of pregnancy for a maternal indication under approved consent of gynecologists. Thin paraffin-embedded sections $(4 \mu \mathrm{m}$ thick) of tissue section were mounted on poly- lysincouted (positively charged) slides for the immunocytological characterization in these tissue sections.

\section{Immunoreagents and immunocytochemical procedures}

Lymphocyte subpopulations were identified by two sets of dual staining monoclonal antibodies labeled with Florescen Isothiocyanate (FITC) and Rhodamin Phycorethin (RPE) as ordered as (anti-CD3-FITC and anti-CD19-RPE, SEROTEC, Cat. No. DC005) and antiCD4-FITC, anti-CD8-RPE, SEROTEC, Cat. No. DC048) respectively.

\section{Direct Dual-Immunofluorescence procedure:}

1. Dewaxing and rehydration: paraffin embedded sections were placed inside a hot air oven at $65^{\circ} \mathrm{C}$ overnight, then dipped in xylene and ethanol containing jars in the following order: Xylene for 5 minutes, fresh xylene for $5 \mathrm{~min}$., absolute ethanol for $5 \mathrm{~min}$., ethanol (95\%) for $5 \mathrm{~min}$., ethanol (70\%) for $5 \mathrm{~min}$., ethanol (50\%) for $5 \mathrm{~min}$. and distilled water for $5 \mathrm{~min}$.

2. For blocking the non-specific binding sites, $100 \mu 1$ of a protein-blocking reagent was placed onto the section and incubated for 10 minutes in a humid chamber at room temperature. Then the slides were drained and blotted gently.

3. $50 \mu \mathrm{l}$ of diluted primary antibody was placed onto the section and incubated for 1 hour at $37^{\circ} \mathrm{C}$ in a humid chamber. After incubation, the slides washed with washing buffer for 5 minutes, drained and blotted gently.

4. Slides were dehydrated by dipping in ascending concentration of ethanol and xylene containing jars in the following order: Ethanol (50\%) for 5 min., ethanol (70\%) for $5 \mathrm{~min}$., ethanol (95\%) for $5 \mathrm{~min}$., absolute ethanol for $5 \mathrm{~min}$., fresh xylene for $5 \mathrm{~min}$.

Two drops of mounting media [(nine parts glycerol to one part of $0.2 \mathrm{M}$ carbonate buffer, $\mathrm{pH}=9$ (Batty, 1986) to enhance fluorescence and retard fading on exposure to UV-light (Narin, 1968)) placed on each smear of slides. Then cover slips were lowered into place slowly to avoid bubbles; cover slips may be sealed around edges with clear nail polish. Slides were examined then with fluorescence microscope at $490 \mathrm{~nm}$; positive cells give green-apple or red when stained were recorded at X400 magnification.

\section{Statistical analysis}

Numerical data were recorded as mean and standard deviation of mean. Independent sample t-test used to compare between study groups and $p$-value $\leq 0.05$ was considered statistically significant.

\section{Results}

\section{Patient's characteristics}

A total of fifty pregnancies divided into three groups were studied. The group I consisted of $19 \mathrm{CHM}$, group II consisted of 16 iCHM and group III consisted of 15 normal pregnancies. Patient characteristics are presented in (Table 1). 
All tissue biopsies were belonging to Iraqi pregnant ladies their mean age control group was $31.7 \pm 9.4$ years, iCHM was $29.32 \pm 6.23$ and CHM was $32.40 \pm 8.21$ all groups were statistically none significant $(\mathrm{p}=0.732)$. There were no differences mean gestational age of all groups were statistically none significant $(\mathrm{p}=0.732)$.

Table 1. Description of study group characteristics.

\begin{tabular}{lllll}
\hline & $\begin{array}{l}\text { Control } \\
\text { group } \\
\text { n=5 }\end{array}$ & $\begin{array}{l}\text { iCHM } \\
\text { group } \\
\text { n=16 }\end{array}$ & $\begin{array}{l}\text { CHM } \\
\text { group } \\
\text { n=19 }\end{array}$ & P value \\
\hline Age (years) & $31.7 \pm 9.4$ & $29.32 \pm 6.2$ & $32.40 \pm 8.2$ & $0.732^{\mathrm{NS}}$ \\
Gravidity & $2-5$ & $2-4$ & $1-6$ & \\
Parity & $1-4$ & $1-4$ & $0-5$ & \\
Gestational & $85.3 \pm 14$. & $74.32 \pm 19$. & $81.92 \pm 17$. & $0.085^{\mathrm{NS}}$ \\
age (days) & 2 & 1 & 21 & \\
\hline
\end{tabular}

Lymphocytic constituents in molar pregnancy and control tissue:

All cases were investigated for CD3/CD19 and CD4/CD8 expression based on dual immunofluorescence staining technique. (Figure 1). Total number of $\mathrm{T}$ cells and subsequent cellular subsets $(\mathrm{CD} 3+, \mathrm{CD} 4+, \mathrm{CD} 8+$, and CD19 cells). $\mathrm{T}$ cells were $36.68 \pm 10.92$ infiltrated in iCHM and 42.62 \pm 9.12 in CHM compared with $27.80 \pm 7.21$ among normal trophoblastic tissues. While, plasma cells were significantly higher in its pattern of infiltration in iCHM 7.08 \pm 1.12 and CHM 6.82 \pm .91 than those in normal trophoblastic tissue $(\mathrm{p}=0.013$ and 0.012 respectively).

Dual immunofluorescence labeling confirmed that the majority of cellular infiltrates were helper cell subtype (CD4) in iCHM 29.33 \pm 12.84 and CHM 34.02 \pm 16.23 than those of control $14.74 \pm 5.32(p=0.025$ and 0.017 respectively). While, cytotoxic cells were not significantly different among study groups (Table 2).

\section{Discussion}

This is the first study describe the lymphocyte subsets infiltration inthe decidual tissuee of hydatid mole disease. The results demonstrate that most decidual $\mathrm{T}$ cells express CD4 $\mathrm{T}$ cell receptors whereas CD8 $\mathrm{T}$ cells comprise only a small proportion compared with normal trophoblastic tissue. These results had been argued by other researchers and they reported that these cells express perforin, granzyme A, granzyme B, granulysin and Fas ligand (FasL) (11-12). Therefore, these cells may protect the maternal-fetal unit from infections, control trophoblast invasion, and create a local immune tolerance toward the semi allogeneic conceptus by killing fetal reactive lymphocytes.
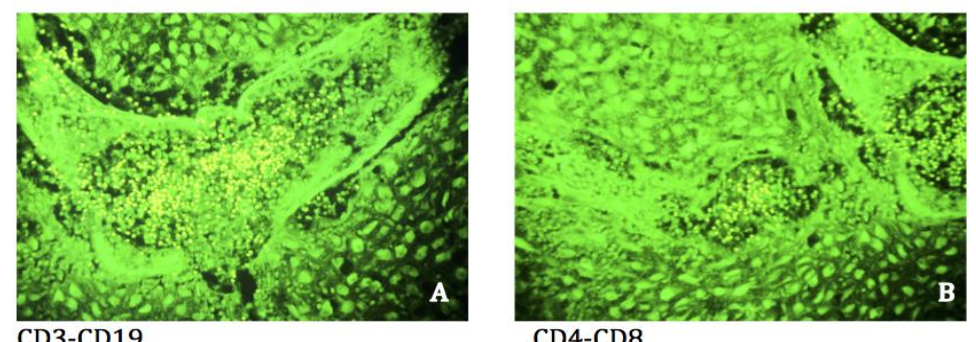
CD3-CD19

CD4-CD8
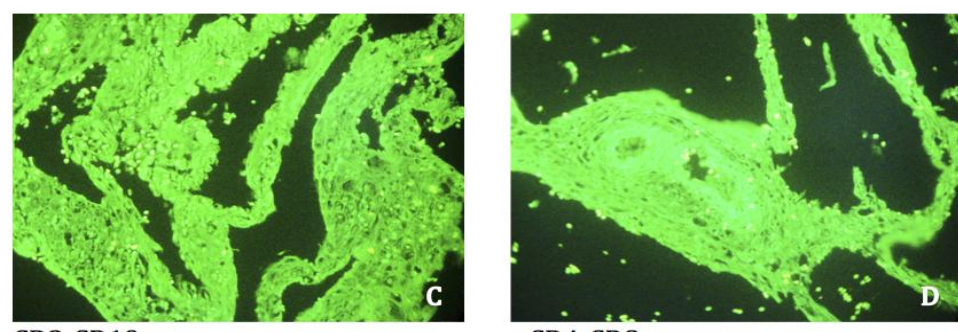

CD3-CD19

CD4-CD8

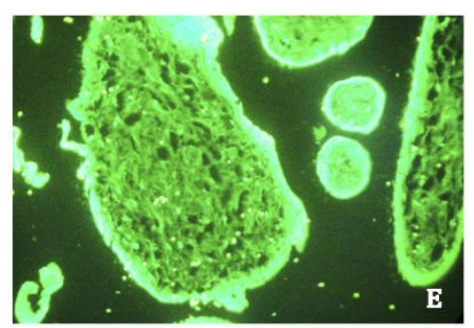

CD3-CD19

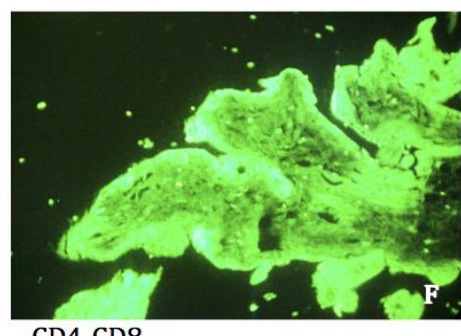

CD4-CD8

Figure 1. Dual immunofluorescence (A and B) CHM, (C and D) iCHM and (E and F) normal tissue. A, C and E stained with Anti (CD3-CD19) antibodies, stained cells can be seen several T-cells (CD3+ve) green color and fewer plasma cells (CD19+ve) red color. B, D and F stained with Anti (CD4, CD8) T-helper (CD4+ve) green color extensively infiltrated (B and D) and fewer T- cytotoxic (CD8+ve) red color infiltration seen.

Table 2. Result of comparison for total $T$ cells and different subsets of $\mathrm{T}$ cells among different study groups.

\begin{tabular}{llll}
\hline & $\begin{array}{l}\text { Normal } \\
\mathbf{N = 5}\end{array}$ & $\begin{array}{l}\text { Incomplete } \\
\text { H mole } \\
\mathbf{N = 1 6}\end{array}$ & $\begin{array}{l}\text { Complete H } \\
\text { mole } \\
\mathbf{N = 1 9}\end{array}$ \\
\hline CD3 & $27.80 \pm 7.21$ & $\begin{array}{l}36.68 \pm 10.92 \\
(0.107 \mathrm{NS})\end{array}$ & $\begin{array}{l}42.62 \pm 9.12 \\
\left(0.003^{*}, 0.089 \mathrm{NS}\right)\end{array}$ \\
CD19 & $5.22 \pm 1.92$ & $\begin{array}{l}7.08 \pm 1.12 \\
\left(0.013^{*}\right)\end{array}$ & $\begin{array}{l}6.82 \pm .91 \\
\left(0.012^{*}, 0.454 \mathrm{NS}\right)\end{array}$ \\
& & $\begin{array}{l}12.9 \pm 8.22 \\
(0.426 \mathrm{NS})\end{array}$ & $\begin{array}{l}14.29 \pm 7.03 \\
(0.605 \mathrm{NS}, 0.593 \mathrm{NS})\end{array}$ \\
CD8 & $16 \pm 3.11$ & $29.33 \pm 12.84$ & $34.02 \pm 16.23$ \\
& & $\left(0.025^{*}\right)$ & $\left(0.017^{*}, 0.357 \mathrm{NS}\right)$ \\
CD4 & $14.74 \pm 5.32$ & $6.3: 1$ \\
& & $5.3: 1$ & $0.41: 1$ \\
\hline
\end{tabular}


Data presented as mean \pm Standard deviation, NS= none statistical significance $(p>0.05) .{ }^{*}=$ statistical significant difference $(p \leq 0.05)$.

Decidual CD4+ T cell numbers are increased in complete and partial hydatidiform moles compared to a normal early pregnancy, and this result was accordance with those in most previous studies by Sanguansermsri and Pongcharoen (7); Dickson et al. (13) these findings suggest an altered maternal immune response against the molar trophoblast compared to a normal pregnancy. The decrease in CD8+ T cells in hydatidiform mole noted in the present study suggests that $\mathrm{CD} 8+\mathrm{T}$ cells may not be primarily responsible for immune responses against the molar trophoblast and do not undergo apoptosis following activation (14).

The low number of CD8+ $\mathrm{T}$ cell possibly due to their down-regulation by two cytokines normally present in the fetoplacental tissue which is interleukin (IL)-15 and transforming growth factor (TGF)- $\beta$ (14- 15). In last years, some in vitro studies have demonstrated that TGF$\beta$ (16) and IL-15 (17) up-regulate the de novo expression of CD94/NKG2A heterodimer killer inhibitory receptor (KIR) complex on CD8+ cytotoxic T cells. This, in turn, results in the inhibition of $\mathrm{T}$-cell receptor-mediated cytotoxicity and cytokine production by CD8+ T cells. Increasing consideration is being paid to the role of mucosal, instead of circulating, lymphocyte subpopulations in the pathogenesis of gestational diseases such as molar pregnancy $(18,19)$. Investigation of tissue sections enables analysis of cell populations and their connection in situ, and also examination of the local microenvironment, will expand our comprehension to the role of the Decidual $\mathrm{T}$ lymphocyte activation in hydatidiform mole and normal pregnancy (20).

\section{Conclusion}

In conclusion the study of immunopathology of hydatidiform molar pregnancy may enhance our understanding of the maternal immune response in normal pregnancy, and the importance of plasma cells and helper cells in molar pregnancy pathogenesis.

\section{Acknowledgement}

The author is grateful to all staff members of the Medical Microbiology Department College of Medicine ALNahrain University for their help and cooperation.

Contributions: The authors contributed equally. Ethics Committee Approval: N.A.
Informed Consent: N.A.

Peer-review: Externally peer-reviewed.

Conflict of Interest: No conflict of interest was declared by the author.

Financial Disclosure: The author declared that this study has received no financial support.

\section{References}

1. Bulmer JN, Morrison L, Longfellow M, Ritson A, Pace D. Granulated lymphocytes in human endometrium: histochemical and immunohistochemical studies. Hum Reprod 1991; 6: 791798.

2. Jones RK, Bulmer JN, Searle RF. Phenotypic and functional studies of leukocytes in human endometrium and endometriosis. In: Human Reproduction Update. 1998. page 702-709.

3. Pace D, Longfellow M, Bulmer JN. Characterization of intraepithelial lymphocytes in human endometrium. J Reprod Fertil 1991; 91: 165-174.

4. Vassiliadou N. Quantitative analysis of $\mathrm{T}$ lymphocyte subsets in pregnant and nonpregnant human endometrium. Biol Reprod 1996; 55: 1017-1022.

5. Scaife PJ, Bulmer JN, Robson SC, Innes B a, Searle RF. Effector activity of decidual CD8+ T lymphocytes in early human pregnancy. Biol Reprod 2006; 75: 562-567.

6. Sebire NJ, Unit TD, Hospital CC. Histopathological diagnosis of hydatidiform mole: contemporary features and clinical implications. Fetal Pediatr Pathol 2010; 29: 1-16.

7. Sanguansermsri D, Pongcharoen S. Pregnancy immunology: Decidual immune cells. Asian Pacific J Allergy Immunol 2008; 26: $171-181$.

8. Kirk E, Papageorghiou AT, Condous G, Bottomley C, Bourne $T$. The accuracy of first trimester ultrasound in the diagnosis of hydatidiform mole. Ultrasound Obstet Gynecol 2007; 29: 70-75.

9. Sunderland C a, Bulmer JN, Luscombe M, Redman CW, Stirrat GM. Immunohistological and biochemical evidence for a role for hyaluronic acid in the growth and development of the placenta. J Reprod Immunol 1985; 8: 197-212.

10. Knoeller S, Lim E, Aleta L, Hertwig K, Dudenhausen JW, Arck PC. Distribution of immunocompetent cells in decidua of controlled and uncontrolled (choriocarcinoma/hydatidiform mole) trophoblast invasion. Am J Reprod Immunol 2003; 50: 41-47.

11. Szekeres-Bartho J. Immunological relationship between the mother and the fetus. Int Rev Immunol 2002; 21: 471-495.

12. Wongweragiat $S$, Searle RF, Bulmer JN. Decidual $T$ lymphocyte activation in hydatidiform mole. J Clin Pathol 1999; 52: 888-894.

13. Dickson-González SM, García de Barriola V, BarbellaAponte RA, Figueira L, Cortés-Charry R, Naranjo de Gómez M. Histopathologic and immunohistochemical evaluation of blood vessels in complete and partial hydatidiform mole. $J$ Reprod Med 2006; 51: 933-937.

14. Jokhi PP, King A, Loke YW. Cytokine production and cytokine receptor expression by cells of the human first trimester placental-uterine interface. Cytokine 1997; 9: 126137.

15. Verma S, Hiby SE, Loke YW, King A. Human decidual 
natural killer cells express the receptor for and respond to the cytokine interleukin 15. Biol Reprod 2000; 62: 959-968.

16. Bertone S, Schiavetti F, Bellomo R, Vitale C, Ponte M, Moretta L, Mingari MC. Transforming growth factor- $\beta$ induced expression of CD94/NKG2A inhibitory receptors in human T lymphocytes. Eur J Immunol 1999; 29: 23-29.

17. Mingari MC, Ponte M, Bertone S, Schiavetti F, Vitale C, HLA class I-specific inhibitory receptors in human $T$ lymphocytes: interleukin 15-induced expression of CD94/NKG2A in superantigen- or alloantigen-activated CD8+ T cells. Proc Natl Acad Sci USA 1998; 95: 1172-1177.

18. Pongcharoen S, Bulmer JN, Searle RF. No evidence for apoptosis of decidual leucocytes in normal and molar pregnancy: implications for immune privilege. Clin Exp Immunol 2004; 138: 330-336.

19. $\mathrm{Xu} \mathrm{Y,} \mathrm{Plazyo} \mathrm{O,} \mathrm{Romero} \mathrm{R,} \mathrm{Hassan} \mathrm{SS,} \mathrm{Gomez-Lopez} \mathrm{N.}$ Isolation of Leukocytes from the Human Maternal-fetal Interface. J Vis Exp 2015; (99): e52863.

20. Liliana $\mathrm{N}$, Mihael $\mathrm{A}$, Maria $\mathrm{M}$, Manolea $\mathrm{S}$. The vasculogenesis - a possible histological identification criterion for the molar pregnancy. Rom J Morphol Embryol 2011; 52: 61-67.
How to cite?

Fasial H, Salman J, Mustafa M, Salman H. Characterization of lymphocyte infiltration in molar pregnancies J Immunol Clin Microbiol. 2016; 1(3).

DOI: dx.doi.org/10.5455/jicm. jicm.18.20161028102134

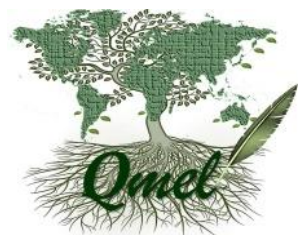

Published by The QMEL.org International Medical Education Library 